\title{
羞明・意識障害・縮瞳をきたした 少量の強オピオイド使用患者
}

\author{
谷川明希子，片山 寛次
}

福井大学医学部 腫瘍病態治療学講座

\begin{abstract}
強オピオイドは癌性疼痛に有用であり, 副作用は悪心・嘔吐, 眠気, 便秘等が知られ, 過量投与では呼吸抑制や意識 障害をきたす，今回，強オピオイド開始直後に悪心と羞明，少量で意識障害と縮瞳をきたした症例を経験した。 79 歳男性が肝細胞癌 stage IVB で肋骨転移あり, 癌性疼痛を認めた。除痛のための強オピオイド開始直後に強い悪心 と羞明を認めた. オキシコドン塩酸塩水和物は強い悪心で中止し, モルヒネ硫酸塩水和物は羞明で中止した. フェン タニル貼付製剤は $1 \mathrm{mg}$ で一過性の健忘, $2 \mathrm{mg}$ で縮瞳と意識障害を認め, 中止した。呼吸抑制は認めなかった。強 オピオイドは羞明もきたしうる. 少量でも縮曈や意識障害をきたす症例もある. 強オピオイド開始時に強い副作用や 羞明を認めた場合には, 少量でも縮瞳や意識障害をきたす可能性があり, 注意した観察が必要である.

Palliat Care Res 2018; 13(2): 147-52
\end{abstract}

Key words: 強オピオイド，羞明，縮曈，意識障害

\section{緒 言}

オピオイドの癌性疼痛への有用性が知られてい る1〜4).わが国では, 強オピオイドにモルヒネ, オキ シコドン, フェンタニル，タペンタドール，ヒドロモ ルフォン，メサドンがある5)。代表的な副作用には, 悪心，傾眠，便秘がある6)。オピオイドは過量投与で 呼吸抑制を生じる危険性がある7)。今回, 強オピオイ ド導入直後に強い悪心と羞明を認め, 少量で縮瞳と意 識障害をきたした症例を経験した。

\section{症例提示}

79 歳男性, 身長 $158 \mathrm{~cm}$, 体重 $47.4 \mathrm{~kg}$. 居酒屋経営 者. 肝細胞癌に対し手術, 塞栓術, ラジオ波焼灼術, 放射線治療, 全身化学療法を施行したが, 多発肺転移 と右胁骨転移を認め, 肋骨部に癌性疼痛を認めた。卜 ラマドール塩酸塩 $37.5 \mathrm{mg}$ とアセトアミノフェン 325 mg 2 錠/日が処方されたが, 強い癌性疼痛で, オキシコ

受付日 2017 年 9 月 21 日 / 改訂日 2018 年 2 月 28 日 / 受理日 2018 年 3 月 5 日

\section{Corresponding Author：谷川明希子}

福井大学医学部附属病院 腫瘍病態治療学講座

干 910-1193 福井県吉田郡永平寺町松岡下合月 23-3

TEL 0776-61-3111 FAX 0776-61-8857

E-mail: famy0101@yahoo.co.jp
ドン塩酸塩水和物 (OXC: Oxycodone hydrochloride hydrate） $5 \mathrm{mg} 1$ 日 2 回とプロクラルペラジン $5 \mathrm{mg} 1$ 日 3 回にオピオイドスイッチングした(図 1).5日後に OXC $10 \mathrm{mg} 1$ 日 2 回に増量したが, 強い悪心あり, 翌 日にOXC 中止した。 Numerical Rating Scale(NRS) 6/10 程度の持続痛と体動時にNRS 7/10 程度に増強する突 出痛を認め, 疼痛コントロール目的に緩和ケアチーム (PCT: Palliative Care Team)に紹介となった. NRS 1/10 程度への持続痛の改善希望あり, 再度 OXC $5 \mathrm{mg} 1$ 日 2 回を開始し, プロクラルペラジン $5 \mathrm{mg} 1$ 日 3 回とオラ ンザピン $5 \mathrm{mg}$ の夕方内服も併用した。強い悪心で 2 日 後に OXC 中止した. トラマドール塩酸塩 $37.5 \mathrm{mg}$ とア セトアミノフェン $325 \mathrm{mg} 2$ 錠/日の使用を再開するも, NRS 6/10 程度の持続痛と咳で誘発される NRS 7/10 程 度の突出痛で夜間の睡眠障害を認めた。オピオイドス イッチングとしてモルヒネ硫酸塩水和物 (MOR) $10 \mathrm{mg}$ の 1 日 1 回内服を開始したが, 強い悪心を認めた。病 室は空側であり，通常では感じない程度の日光で患者 はまぶしく感じ，羞明でサングラスを使用する状態で あった。その際の眼所見はとっておらず，縮曈や散瞳 の有無は不明であった。中枢神経に作用する薬剤は, ゾピクロン $7.5 \mathrm{mg}$ 就寝前, プロクラルペラジン $5 \mathrm{mg} 1$ 日 3 回, オランザピン $5 \mathrm{mg}$ 就寝前, ラメルテオン $8 \mathrm{mg}$ 就寝前を使用していたが，いずれも羞明出現以前より 使用していた。体温上昇や頭痛, 痤攣や麻痺, 認知機 能障害などは認めず，急激な頭蓋内疾患の出現による 羞明の可能性は低く, 直近に使用した MORの影響が 


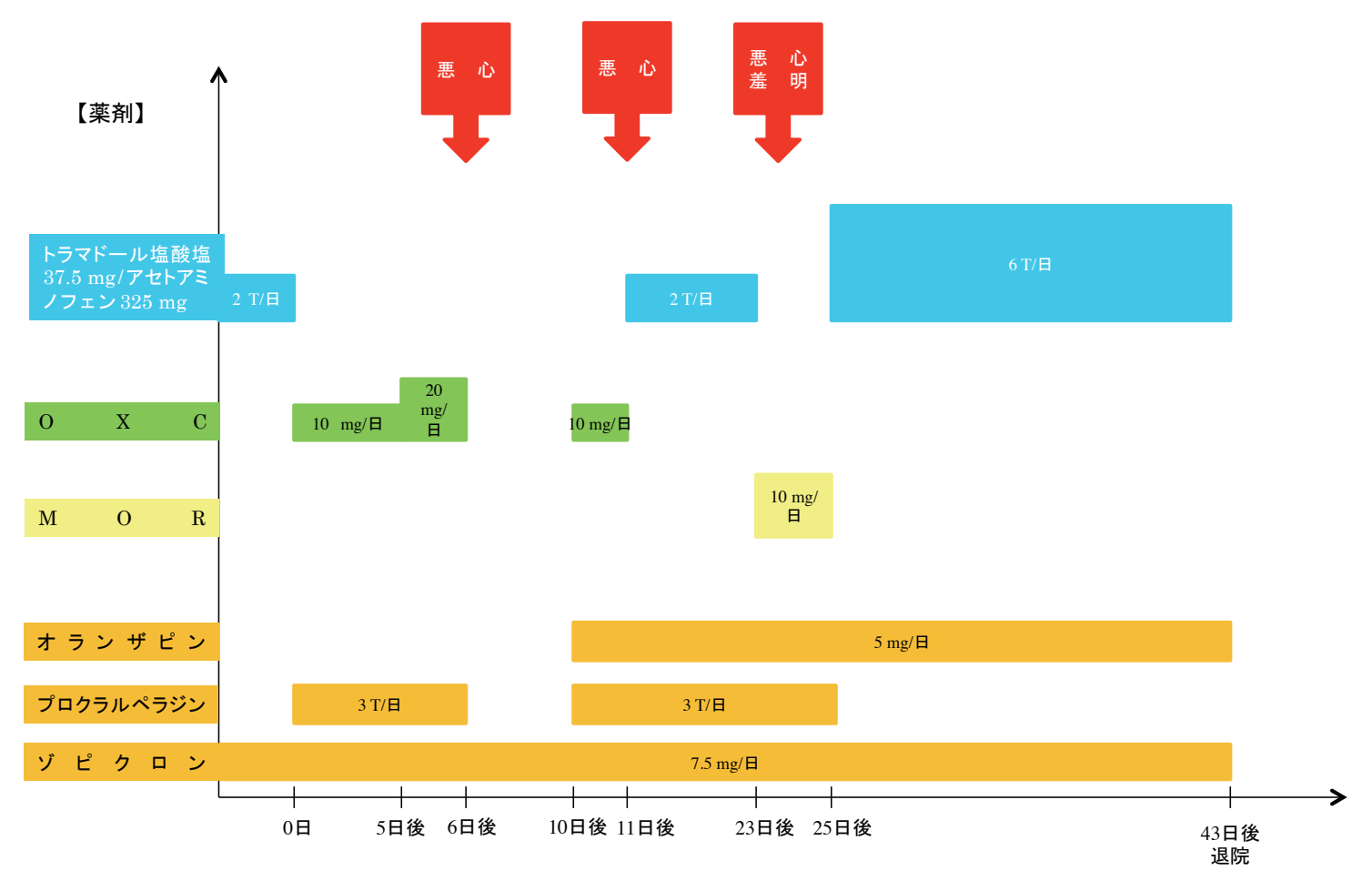

【日数】

図 11 回目入院後経過

高いと考え，2 日後に中止した．中止後は速やかに悪 心と羞明は改善した。 トラマドール塩酸塩 $37.5 \mathrm{mg}$ と アセトアミノフェン $325 \mathrm{mg} 6$ 錠/日でNRS 4/10 程度に 持続痛は改善を認め, 退院となった。この間, Performance Status (PS) 1〜2 を保ち，原疾患に対し 5-FU 500 mg 5 日間, シスプラチン $5 \mathrm{mg} 5$ 日間 (low-dose FP 療法) を施行した。化学療法の悪心対策で, グラニセトロン 塩酸塩の点滴, アプレピタントを使用した。脳転移な く, 頭部への放射線治療などは行っていなかった.

2 力月後に肺炎と NRS 6/10 程度の持続痛で入院し た。これ以上の原疾患に対する積極的加療の希望な く, 抗生剂加療と疼痛コントロールでフェンタニル貼 付製剤 $1 \mathrm{mg}$ にオピオイドスイッチングした(図 2). こ れまで健忘症状が出現したことはなかったが, オピオ イドスイッチングの 2 日後に「朝食摂取したことを忘 れる」一過性の健忘が出現したものの, 見当識障害は 認めず, 悪心や羞明も認めなかった。 NRS 4/10 程度の 持続痛継続し, 同薬 $2 \mathrm{mg}$ へ増量した。持続痛はNRS 2/10 程度に落ち着いたが, 7 日後より傾眠傾向認め, 意識レベルはJapan Coma Scale (JCS)II-1 と低下した. 両側瞳孔は $2 / 2 \mathrm{~mm}$ と縮瞳を認めた。呼吸回数 (RR: respiratory rate) は 12 回/分と低下なく, 呼びかけに容易 に開眼した。同薬 $1 \mathrm{mg}$ へ減量し，8 日後にJCS I-3 と 見当識障害を認めたが, 自発開眼した. RR 16 回/分と
低下なく, 両側瞳孔 $2 / 2 \mathrm{~mm}$ と縮瞳継続した. 9 日目に RR 11 回/分であったが, JCS II-2 と悪化し, 縮瞳継続 し, 同薬中止した。橋出血除外で, 頭部 CT を撮影し たが異常なく，アンモニア值も正常であった(表 1). 10 日目には縮睲継続したが, JCS I-2 に改善した。加療 継続目的に転院となった。フェンタニル血中濃度は, LSI メディエンス(株)に依頼して行い, 貼付製剤導入 前 $0.1 \mathrm{ng} / \mathrm{ml}$ 未満, 7 日目 (フェンタニル貼付製剤 $2 \mathrm{mg}$ ) $0.8 \mathrm{ng} / \mathrm{ml}$, 9 日目 $1.1 \mathrm{ng} / \mathrm{ml}$ であった。転院先で, 再度 OXC $5 \mathrm{mg} 1$ 日 2 回導入し, 持続痛は NRS 3/10 程度で あり, 羞明, 縮瞳や意識障害は生じず経過している。

\section{考 察}

本症例で, 以下 2 点が示された。 (1)強オピオイドで 羞明をきたすこと, (2)少量で意識障害と縮瞳を認める ことがあり，呼吸抑制にも注意を要すること。

強オピオイドで羞明をきたすことがある．強オピオ イドの副作用は, 便秘, 悪心, 傾眠, 呼吸困難, せん 妄などがある ${ }^{8)}$. わが国の 2004 年 4 月〜2013 年 11 月 までの副作用デー夕解析の報告の中に羞明は認めてい ない6). 医中誌で「オピオイド」・「副作用」・「羞明」の 検索で，フェンタニル貼付製剤で羞明感が出現した症 例報告の会議録 1 例のみであった ${ }^{9)}$. Pub med で「opi- 


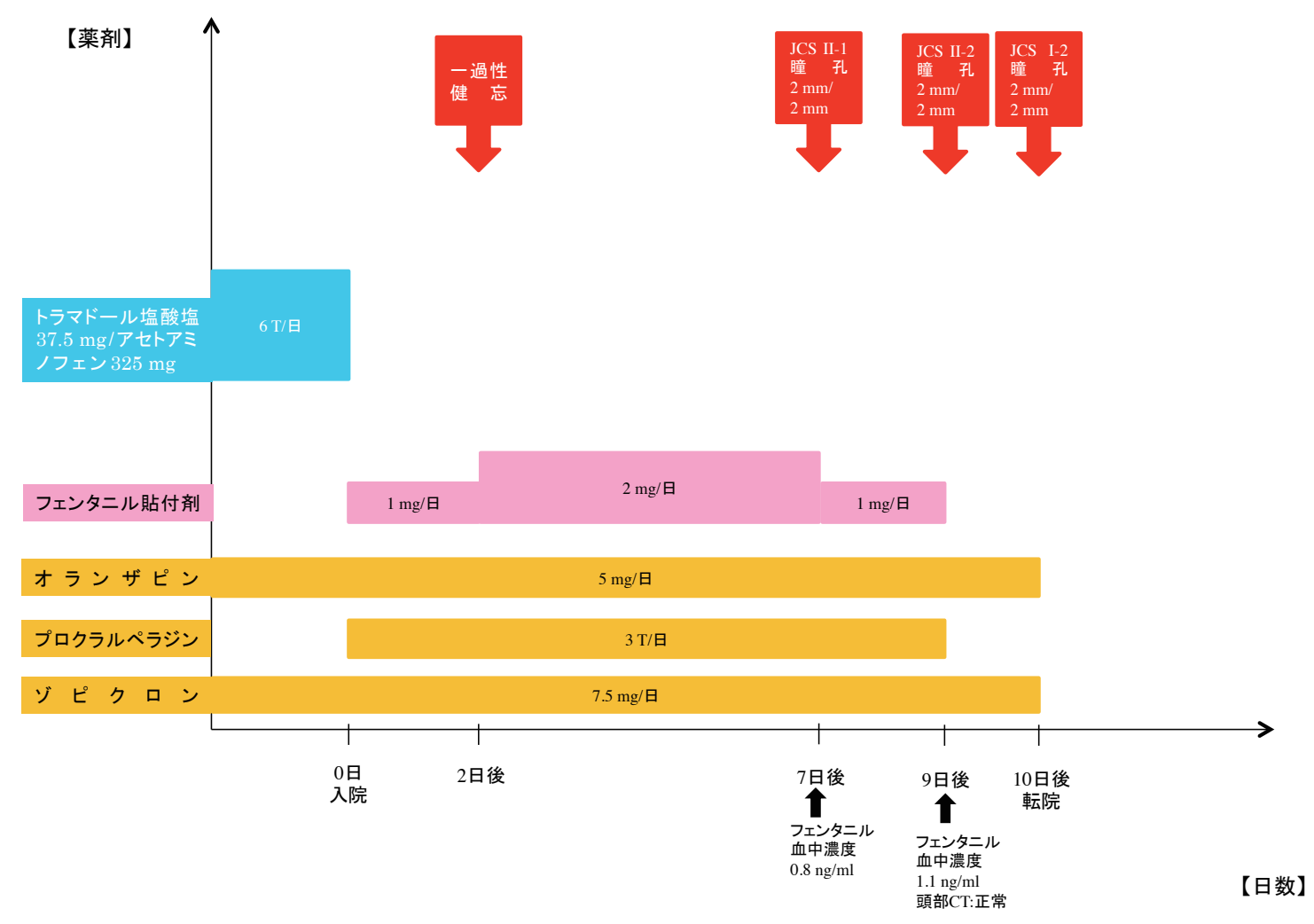

図 22 回目入院後経過

\section{表 12 回目入院後 9 日目採血}

\begin{tabular}{|c|c|c|c|}
\hline \multirow{2}{*}{$\begin{array}{c}\text { 末梢血液検査 } \\
\text { WBC }\end{array}$} & \multicolumn{3}{|c|}{ 生化学検査 } \\
\hline & $5500 / \mu \mathrm{l}$ & $\mathrm{Na}$ & $135 \mathrm{mEq} / \mathrm{L}$ \\
\hline $\mathrm{Hb}$ & $8.0 \mathrm{~g} / \mathrm{dl}$ & $\mathrm{K}$ & $4.7 \mathrm{mEq} / \mathrm{L}$ \\
\hline \multirow[t]{2}{*}{ Plt } & $19.5 \times 10^{4} / \mu 1$ & $\mathrm{Cl}$ & $100 \mathrm{mEq} / \mathrm{L}$ \\
\hline & & $\mathrm{Ca}$ & $8.1 \mathrm{mg} / \mathrm{dl}$ \\
\hline \multicolumn{2}{|l|}{ 凝固検査 } & T-bil & $0.60 \mathrm{mg} / \mathrm{dl}$ \\
\hline PT & $93.6 \%$ & D-bil & $0.20 \mathrm{mg} / \mathrm{dl}$ \\
\hline \multirow[t]{2}{*}{ HPT } & $79.0 \%$ & I-bil & $0.40 \mathrm{mg} / \mathrm{dl}$ \\
\hline & & $\mathrm{TP}$ & $6.9 \mathrm{~g} / \mathrm{dl}$ \\
\hline \multicolumn{2}{|l|}{ 免疫学的検査 } & Alb & $2.0 \mathrm{~g} / \mathrm{dl}$ \\
\hline \multirow[t]{10}{*}{ CRP } & $8.06 \mathrm{mg} / \mathrm{dl}$ & $\mathrm{CK}$ & $23 \mathrm{IU} / \mathrm{L}$ \\
\hline & & AST & $108 \mathrm{IU} / \mathrm{L}$ \\
\hline & & ALT & $155 \mathrm{IU} / \mathrm{L}$ \\
\hline & & LDH & $193 \mathrm{IU} / \mathrm{L}$ \\
\hline & & ALP & $555 \mathrm{IU} / \mathrm{L}$ \\
\hline & & Г-GTP & $84 \mathrm{IU} / \mathrm{L}$ \\
\hline & & CRNN & $0.83 \mathrm{mg} / \mathrm{dl}$ \\
\hline & & BUN & $26 \mathrm{mg} / \mathrm{dl}$ \\
\hline & & BS & $75 \mathrm{mg} / \mathrm{dl}$ \\
\hline & & アンモニア & $30 \mu \mathrm{mol} / \mathrm{L}$ \\
\hline
\end{tabular}

oid $」 \cdot\lceil$ side effect $」 \cdot\lceil$ photophobia $」 の$ 検索で報告は認め なかった。オピオイドは大部分が $\mu$ 受容体作動薬であ $3^{10)}$. $\mu$ 受容体は, 体性感覚経路である春䯣後角や脳 幹, 視床, 大脳知覚領で高発現が認められてい
る ${ }^{11 \sim 13)}$ ，非オピオイド使用者では，片頭痛患者で羞明 をきたすことがあり，視床と網膜からの光刺激と視床 皮質経路の関係性が言われている ${ }^{14,15)}$. $\mu$ 受容体は視 床にも分布し， $\mu$ 受容体作動薬であるオピオイドが羞 明をきたす可能性は十分にあると考えられる。本症例 では, モルヒネ導入直後に羞明をきたし, 中止後は速 やかに症状改善した。中枢神経に作用する薬剤の使用 もあり，薬物相互作用を示した可能性はあると考えら れる。本症例は，モルヒネで羞明をきたした第 1 例で ある。

強オピオイドは少量で意識障害と縮瞳を認めること があり，呼吸抑制にも注意が必要である。腎不全患者 や透析患者では, $20 \mathrm{mg} /$ 日程度のモルヒネ投与で意識 障害や呼吸抑制を生じた症例はあるが16)，本症例では 腎不全はなかった。腎不全がない患者では，フェンタ ニル口腔粘膜吸収剤 $100 \mu \mathrm{g}$ の投与 6 時間後に意識障害 を認めた症例はあるが17)，われわれが検索した範囲内 で腎機能正常の患者で少量の強オピオイドで意識障害 をきたした報告は認めなかった。 オピオイドは瞳孔括 約筋を活性化し, 縮瞳を引き起こす ${ }^{18)}$. 中毒量の $\mu$ 作 動薬投与後では, 縮瞳が著明であり, 点状曈孔 pinpoint pupil が特徴的である ${ }^{19)}$. 少量のオピオイドによる縮瞳 は報告されていない。本症例では, フェンタニル貼付 製剤 $1 \mathrm{mg}$ で一過性健忘が生じ, $2 \mathrm{mg}$ で縮瞳と意識障 
害が生じた. $1 \mathrm{mg}$ に減量後も縮曈と意識障害が遷延 し, 経口モルヒ不換算 $30 \mathrm{mg} /$ 日程度の少量のフェンタ ニルで縮曈と意識障害をきたした第 1 例である。しか し，フェンタニルの血中への以降が急峻であり少量で も意識障害や縮曈が生じた可能性も考え, 血中濃度測 定を行った。貼付製剤 $2 \mathrm{mg}$ 導入 7 日目に $0.8 \mathrm{ng} / \mathrm{ml}$ と 高值は認めず, 7 日目に同薬 $2 \mathrm{mg}$ から $1 \mathrm{mg}$ へ減量し たが, 9 日目の血中濃度は $1.1 \mathrm{ng} / \mathrm{ml}$ と上昇を認め, フェ ンタニル製剤が体内に遷延している可能性は考えら れた。

オピオイドによる呼吸抑制は，用量依存的な延髄の 呼吸中枢への直接作用による ${ }^{20)}$. 呼吸抑制を生じる症 例は，オピオイド過量投与によると考えられる。 オピ オイドで呼吸抑制をきたした症例では縮曈を伴ってい

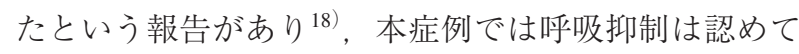
いないが，縮曈を認める際には，呼吸抑制にも十分な 注意が必要である。

本症例では，モルヒネで羞明をきたし，フェンタニ ルで縮瞳と意識障害を認めた症例だが，いずれも少量 の強オピオイド量であった。 また，強オピオイド導入 時に強い悪心が出現し, 制吐薬使用したがコントロー ル困難であり，強オピオイドに対する感受性が高い可 能性は考えられた。

オピオイドの過量投与で有害事象を生じる文献は認 めるが21)，少量での報告は認めない，本症例では経口 モルヒ六換算 $45 \mathrm{mg} /$ 日の弱オピオイドであるトラマ ドール塩酸塩では副作用は認めず, NRS $2 / 10$ 程度の持 続痛を認めて抢り, 強オピオイドの相対的な過量投与 が副作用出現の原因の可能性は低いと考元られる。ま たモルヒネ・フェンタニルの強オピオイドで羞明や 縮曈の視神経障害を生じており，視床に分布する $\mu$ 受 容体への個人的な特異性がある可能性も示唆される.

しかし,オキシコドンでは羞明や縮瞳は認めておら ず，その作用機序には疑問点も多い.

強オピオイドで羞明をきたし, 少量投与で意識障害 と縮曈を示し得ることがわかった，少量の強オピオイ ドで強い副作用や羞明を認めた際には，意識障害や縮 曈を示すことがあり，呼吸抑制にも注意した観察が必 要である。ただし，本所見は 1 例から得られた示唆で あり, 今後羞明や意識障害, 縮瞳を示す症例を集積 し，どのような症例において特異的な副作用が強く出 現するのかの特徴づけも重要だ.

\section{結 語}

強オピオイドで羞明・意識障害・縮瞳を認めた症例 を経験した，過量投与で意識障害や呼吸抑制をきたす ことがあるが, 本症例では少量投与で羞明・意識障
害・縮曈を認めている。特異的な副作用出現時には, 呼吸抑制にも注意した観察が必要である。

著者の申告すべき利益相反なし

谷川抄よび片山は, 研究の構想もしくはデザイン, 原 稿の重要な知的内容に関わる批判的な推敲に貢献; 谷 川は, 研究デー夕の収集, 分析, 研究デー夕の解釈, 原稿の起草に貢献した。全ての著者は投稿論文ならび に出版原稿の最終承認, 抄よび研究の説明責任に同意 した。

\section{文 献}

1) Hanks GW, Conno F, Cherny N, et al. Morphine and alternative opioids in cancer pain: the EAPC recommendations. $\mathrm{Br} \mathrm{J}$ Cancer 2001; 84: 587-93.

2) World Health Organizaion. Cancer Pain Relief, second edition. World Health Organizaion, Geneva, 1996; 12-29.

3) Caraceni A, Hanks G, Kaasa S, et al. Use of opioid analgesics in the treatment of cancer pain: evidence-based recommendations from the EAPC. Lancet Oncol 2012; 13: e58-68.

4）オピオイドの選択, オピオイド治療の目的, オピオイド 治療が対象となる疾患. 非がん慢性[疼]痛に対するオ ピオイド鎮痛薬処方ガイドライン作成ワーキンググ ループ 編. 非がん慢性[疼]痛に対するオピオイド鎮痛 薬処方ガイドライン。真興交易, 東京, 2012;24-9.

5）浜野 淳, 山本 亮. 非オピオイド鎮痛薬で十分な鎮痛 効果が得られない，または，中等度以上の痛みのあるが ん患者. 緩和医療ガイドライン作成委員会 編. がん疼 痛の薬物療法に関するガイドライン。金原出版, 東京, 2014; 137-45.

6）永井純子, 植沢芳広, 加賀谷肇. わが国の医薬品副作用 データベースに基づく強オピオイドによる副作用の特 徵解析一モルヒネ・フェンタニル・オキシコドンによる 副作用の発現傾向と特徵一. Palliative Care Research 2015; 10: 113-9.

7）亀井淳三. 日本におけるオピオイド鎮痛薬の臨床と基 礎研究の展望. オピオイド鎮痛薬による呼吸抑制の基 礎と臨床での対策：新たな展開(解説/特集)。ペインク リニック 2017; S99-106.

8) McNicol E, Horowicz-Mehler N, Fisk RA, et al. Management of opioid side effects in cancer-related and chronic noncancer pain: a systematic review. J Pain 2003; 4: 231-56.

9）濱田宏, 中村隆治, 仁井内浩, 他. 経皮吸収型フェン タニル製剂使用開始後に著明な吃音と羞明感が出現し た神経障害性疼痛の 1 例。日本ペインクリニック学会誌 2011; 18: 265.

10) Narita M, Nakamura A, Ozaki M, et al. Comparative pharmacological profiles of morphine and oxycodone under a neuropathic pain-like state in mice: evidence for less sensitivity to morphine. Neuropsychopharmacology 2008; 33: 1097-112.

11) Lutz PE, Kieffer BL. Opioid receptors: distinct roles in mood disorders. Trends Neurosci 2013; 36: 195-206.

12) Le Merrer J, Becker JA, Befort K, et al. Reward processing by the opioid system in the brain. Physiol Rev 2009; 89: 1379- 
412.

13) Bailey A, Ledent C, Kelly M, et al. Changes in spinal delta and kappa opioid systems in mice deficient in the $\mathrm{A} 2 \mathrm{~A}$ receptor gene. J Neurosci 2002; 22: 9210-20.

14）仲泊 聡. 羞明と脳. 神経眼科 2016; 33: 344-50.

15) Noseda R, Burstein R. Advances in understanding the mechanisms of migraine-type photophobia. Curr Opin Neurol 2011; 24: $197-202$

16）和泉典子, 奥山慎一郎, 阿部和人, 他. がん疼痛に対す る硫酸モルヒネ徐放錠内服後に意識障害と呼吸抑制が 遷延し長期のナロキソン投与を要した血液透析患者の 1 例. 癌と化学療法 2012; 39: 1295-9.

17）李 美於, 新城拓也. フェンタニル舌下錠を投与後 6 時 間後に意識障害を来した 1 例. Palliative Care Research 2015; 10: 527-30.
18) Rollins MD, Feiner JR, Lee JM, et al. Pupillary effects of high-dose opioid quantified with infrared pupillometry. Anesthesiology 2014; 121: 1037-44.

19）グッドマン・ギルマン．中枢神経に作用する薬物．高折 修二, 福田英臣, 他, 監訳. グッドマン・ギルマン 薬 理書・第 11 版一薬物治療の基礎と臨床一. 廣川書店, 東京, 2006; 688 .

20）岡本禎晃. オピオイドによる副作用と対策一その他の 副作用と対策。緩和医療ガイドライン作成委員会 編. がん疼痛の薬物療法に関するガイドライン (2014年版). 金原出版，東京，2014; 60 .

21) Bohnert AS, Valenstein M, Bair MJ, et al. Association between opioid prescribing patterns and opioid overdose-related deaths. JAMA 2011; 305: 1315-21. 


\title{
Case Report
}

\section{A Patient Treated with Small-dose Strong Opioids Experienced Photophobia, Disturbance of Consciousness, and Miosis}

\author{
Akiko Tanikawa and Kanji Katayama \\ Oncological Sciences and Treatments, Division of Medicine, Faculty of Medical Sciences, University of Fukui
}

\begin{abstract}
Strong opioids are useful for managing cancer pain, and common side effects include nausea, vomiting, drowsiness, and constipation. Opioid overdose is known to cause respiratory depression and disturbance of consciousness. We observed a 79-year-old man with stage IVB hepatocellular carcinoma with metastasis to the rib and cancer-related pain being treated with strong opioids who, in spite of receiving a small dose and start volume, experienced strong nausea, photophobia, disturbance of consciousness, and miosis. Oxycodone was stopped to manage the strong nausea, and morphine was stopped to manage the photophobia. Furthermore, fentanyl patch was stopped to manage the disturbance of consciousness and miosis. He did not experience respiratory depression. Thus, photophobia, disturbance of consciousness, and miosis can appear as side effects even at small doses of strong opioids. The results reveal two important clinical issues: (1) photophobia can arise as a side effect of strong opioids, and (2) if photophobia, miosis, disturbance of consciousness arise in opioid-treated patients, they require careful monitoring.
\end{abstract}

Palliat Care Res 2018; $13(2): 147-52$

Key words: strong-opioid, photophobia, miosis, disturbance of consciousness 